The Journal of Public Space

ISSN 2206-9658

2020 | Vol. 5 n. 2

https://www.journalpublicspace.org

\title{
EDITORIAL
}

\section{Public health and well-being in public open spaces through climate responsive urban planning and design}

\section{Silvia G. Tavares}

University of the Sunshine Coast, School of Social Sciences, Australia James Cook University, College of Science and Engineering, Australia stavares@usc.edu.au

David Sellars

James Cook University, College of Public Health, Medical \& Vet Sciences, Australia david.sellars@jcu.edu.au

\section{Greg Mews}

Urban Synergies Group, Australia

Queensland University of Technology, School of Design, Creative Industries Faculty, Australia gregor.mews@qut.edu.au

\section{Karine Dupré}

Griffith University, Griffith Architecture \& Design, Australia

k.dupre@griffith.edu.au

\section{Christhina Cândido}

The University of Sydney, School of Architecture, Design and Planning, Australia christhina.candido@sydney.edu.au

\section{Simon Towle}

The Cairns Institute, James Cook University, Australia

simon.towle@jcu.edu.au

\section{Scope}

The urban fabric enables people to move between climate-controlled environments (such as home and indoors work) and non-controlled ones (such as parks and beaches). The planning and design of urban spaces, on the other hand, largely define the way we live and affect our health as it can, for instance, promote or hinder active lifestyles and social cohesion (Owen, 2009; Speck, 2012). But even when the cities have compact built form and provide key features and infrastructure conducive to healthy lifestyles, local climate can indirectly dictate and restrict the use of public open spaces if the weather is prohibitive (Tavares \& Swaffield, 2017). Climate responsive urban planning and design is, therefore, key to secure a healthy urban lifestyle (Barton, Thompson, Burgess, \& Grant, 2015; Kent et al., 2017; Mouratidis, 2017) especially in light of frequency and severity of extreme weather events. 
The impacts of climate responsive urban planning and design can also be observed through the factor determining the degree of inclusiveness or exclusiveness of social environments in which a broad range of people can spend time in. In addition, all aspects of public health have a relationship with local microclimates (Brown, Vanos, Kenny, \& Lenzholzer, 2015; Monteiro \& Velho, 2014) which are also set to be impacted by climate change. The extent of the changes of those microclimates is largely unknown and need to be better understood. As many places are experiencing harsher climate conditions and more extreme weather on macro scale, it is fundamental to plan for the current micro conditions in order to build resilience and adapt well to future challenges.

In terms of healthy lifestyles in conducive microclimates, moderate to rigorous level of physical activity is one of the most effective ways to reduce stress as part of everyday life (Ivory et al., 2015). Aspects of urban life such as walkability, connectivity, mixed-use, diversity of uses, architecture and urban design qualities, and increased density (Iravani \& Rao, 2019) affect the level of activity people consciously and unconsciously decide to undertake. Urban planning and design that seeks to avoid urban sprawl in order to bring people closer together is a core pillar when designing for healthy lifestyles. These design attributes include e.g. active travel (walking, cycling, access to public transport), transit oriented developments (TOD's), easy access to public open spaces (Carmona, Tiesdell, Heath, \& Oc, 2010; Dannenberg, Frumkin, \& Jackson, 20I I; Speck, 20I2, 20I8). Easy access to - and the use of - public open space is important for daily physical activity, meaningful experiences in public places, social encounters with strangers and close friends are fundamental aspects for building a healthy community. If people are close, social encounters among each other will naturally happen, and they will see themselves more frequently and build relationships that make them feel included (Gehl, 20I0; Gehl, Kaefer, \& Reigstad, 2006). Thus, this can contribute to the improvement of their sense of community and belonging, as well as place identity and, consequently, impact their personal mental health.

In recent years the traditional urban planning - focused on urban infrastructure, transportation, land use and housing - has experienced a paradigm shift towards a peoplecentred approach. The New Urban Agenda (2016) plays a key role and shifted the attention to health and well-being and part of city-making processes and policies (Mews, Muminovic, \& Tranter, 2018). This special issue, 'Public health and well-being in public open spaces through climate responsive urban planning and design', of The Journal of Public Space focuses on the nexus and interrogates the relationship between these dimensions of human life. This issue is premised on the belief that for the United Nations New Urban Agenda - adopted in Quito at the Habitat III Conference on Housing and Sustainable Urban Development (UN-Habitat, 2016) - to work locally it is necessary more than overall regulations or importing solutions from elsewhere. Climate can vary within short distances and the way public open spaces are designed must also vary according to the climatic characteristics of each place. The contributions in this issue come from Finland, China, The Netherlands, Italy, Japan, Switzerland and Rwanda.

While there has been a shift to a people-centred approach to urban planning and design, we acknowledge the current situation where public life has come to a standstill in the face of COVID-19. In this context, places of community cohesion have become potential places for disease outbreak. The urban health challenges presented by COVID-19 are unprecedented in modern times and will certainly impact on how cities are planned and designed in the future. In addition, public open spaces are crucial for the return to 
normality once COVID- 19 is less of a threat. While we acknowledge all the challenges upon and ahead of us, the contributions to this special issue were collected long before the infectious outbreak as this publication was idealised following up a UN-Habitat Urban Thinkers Campus (UTC) organised by Silvia Tavares and David Sellars held at James Cook University in Cairns and Townsville (Queensland, Australia) in June 2018, with the significant contribution of Gregor Mews, Karine Dupré and Simon Towle. The UTC gathered experts from various disciplines to discuss the relationships between Urban Planning, Urban Design and Public Health. The discussions helped frame locally based actions - at the event focused on the local tropical climate - to advance Cairns and Townsville towards achieving the Sustainable Development Goals (SDGs) (see Tavares \& Sellars, 2018).

\section{Content}

The content of this special issue is organised based on three main themes: space, society and systems. The first two papers are focused on space. In the first paper, Zhen Xu argues that adverse changes of microclimate are more likely a consequence of local developments than a consequence of global climate change. The author uses CFD (Computational Fluid Dynamics) simulations to compare winter and summer airflow patterns. Results provide evidence to put the microclimate issue (and specifically wind studies) firmly on the agenda of public well-being policy, involving various stakeholders in the development and assessment of urban design code.

In the second article, Marco Maretto, Barbara Gherri, Anthea Chiovitti, Greta Pitanti, Francesco Scattino and Nicolò Boggio used Viterbo (Italy) as a case study to analyse the city as a combination of 'fabrics', including the social, economic and cultural ones. The analysis is based on the morphology of the city and its potential to make the city centre an accessible, pedestrian and child-friendly neighbourhood. The authors focus on the interplay between urban morphology and sustainability and take the city design as a way of controlling the environment. In this regard, microclimate becomes a focus and, when analysed from a combined design and climate data perspective, it can enhance social interaction, enable energy saving in buildings and promote healthy and comfortable urban environments.

The next three papers are focused on the society and how the planning and design of public spaces impacts how societies function and are organised. In the third article in this special issue, Essi Oikarinen focuses on expanding the understanding of climatic experiences both on practical and empirical dimensions. Oikarinen argues that despite the recent developments in dealing with weather, seasonality still affects the rhythm of life and willingness to spend time outside, undermining the local population's health and wellbeing. The author focuses on the 'white space' of the sub-Arctic region to highlight the potential of developing winter-related spaces which - based on the local urban spaces' affordances - have the potential of adding to the local population's healthy habits. In the following contribution, Satoshi Sano, Ivan Filipović and Darko Radović discuss the advantages of low-rise high-density residential buildings in Tokyo. The authors highlight that, as in many other places, Tokyo has been moving towards a high-rise low-density urban fabric. Their work shows the bioclimatic and cultural advantages of the traditional urban morphology. In conclusion, the study demonstrates how the design requirements 
of bioclimatically responsive semi-exterior spaces coincide with desirable public-private human interaction.

In the fifth paper Marlyne Sahakian, Manisha Anantharaman, Antonietta Di Giulio, Czarina Saloma, Dunfu Zhang, Rupali Khanna, Srikanth Narasimalu, Abigail Marie Favis, Cherie Audrey Alfiler, Sumana Narayanan, Xin Gao and Chenxin Li discuss the importance of green public spaces for sustainable well-being. The study is based on case studies of four South and Southeast-Asian mega-cities, which are in various climatic regions - tropical, subtropical and temperate. The study contributes to the understanding of how different activities are carried out in parks by diverse groups of people, and it concludes discussing tensions that may arise due to the various interests and uses involved.

The next two articles are focused on systems. Kaoru Matsuo, Rui Izumiyama, Shihona Arai, Akiko Tanimura and Yusuke Horie developed an analysis of public space use and thermal environmental and wind conditions to support the design of attractive public spaces in Saitama (Japan) New Urban Centre Area. The study was based on the fact that, due to strict regulations in Japan, there are many underused public spaces due to the lack of use flexibility. The authors propose that visualisation is an effective way of generating discussions towards achieving public consensus through stakeholders' discussions. This consensus is fundamental to develop practical and effective 'placemaking'.

In the last contribution, Ilija Gubic and Oana Baloi present Rwanda's response to urban population growth and 2050 strategic vision based on Green Growth and Climate Resilient Strategy. The study is based on six secondary cities identified as economic nodes of growth and which are currently reviewing their masterplans. The article presents the results of public open spaces assessment and participatory design workshops. It also reports policy changes intended at promoting public open spaces as crucial for healthy urban lifestyles.

To conclude this special issue, two viewpoints highlight important matters focusing on the relevance of understanding the local context. The first one is written by Chuck Wolfe, author of Urbanism Without Effort (Wolfe, 2019) and Seeing the Better City (Wolfe, 2017), the latter carrying important influence in the 2018 UTC. The second viewpoint was written by Jill Chism, a local artist from Cairns (Australia), who produced the piece Ponds Dreaming featured on the cover of this special issue. Jill's work is focused on enhancing the awareness of the impact of people on the local environments and ecosystems, and her viewpoint presents different challenges artists may find when commissioning public art works.

\section{Concluding remarks}

UN-Habitat's New Urban Agenda provides a new focus and adds momentum to the research and discussions related to the importance of fair urban environments. Under the auspices of the United Nations, it is imperative that the urban environments - of today and of the future - motivate people to be active, provide frequent and meaningful encounters promoting social connections and consequent inclusion for all citizens. This special issue argues for planning and design of healthy cities for all people by taking context, culture and climate into account. Largely based on case studies coming from diverse geographic locations, the articles in this publication provide valuable evidence of the importance of climate responsive design in promoting healthy future cities. 


\section{References}

Barton, H., Thompson, S., Burgess, S., \& Grant, M. (Eds.). (20I5). The Routledge Handbook of Planning for Health and Well-Being: Shaping a sustainable and healthy future. Routledge.

Brown, R. D., Vanos, J., Kenny, N., \& Lenzholzer, S. (2015). Designing urban parks that ameliorate the effects of climate change. Landscape and Urban Planning, |38, I I8-131. https://doi.org/I0.1016/j.landurbplan.2015.02.006.

Carmona, M., Tiesdell, S., Heath, T., \& Oc, T. (2010). Public Places - Urban Spaces. Taylor \& Francis.

Dannenberg, A. L., Frumkin, H., \& Jackson, R. (20I I). Making healthy places: designing and building for health, well-being, and sustainability. Washington, D.C: Island Press.

Gehl, J. (2010). Cities for People. Washington DC, USA: Island Press.

Gehl, J., Kaefer, L. J., \& Reigstad, S. (2006). Close encounters with buildings. Urban Design International, II(I), 29-47. https://doi.org/I0. I057/palgrave.udi.9000I62.

Iravani, H., \& Rao, V. (2019). The effects of New Urbanism on public health. Journal of Urban Design, 00(00), I-18. https://doi.org/I0.1080/I3574809.2018.1554997.

Ivory, V. C., Russell, M., Witten, K., Hooper, C. M., Pearce, J., \& Blakely, T. (2015). What shape is your neighbourhood? Investigating the micro geographies of physical activity. Social Science \& Medicine (1982), 133, 313-32I. https://doi.org/l0.1016/j.socscimed.2014.1I.04I.

Kent, J. L., Harris, P., Sainsbury, P., Baum, F., McCue, P., \& Thompson, S. (2017). Influencing Urban Planning Policy: An Exploration from the Perspective of Public Health. Urban Policy and Research, I / 46(March), I-15. https://doi.org/10.1080/08I I I 146.2017.I299704.

Mews, G. H., Muminovic, M., \& Tranter, P. (2018). Time for action. Implementing the New Urban Agenda in public spaces for health and wellbeing. The Journal of Public Space, 3(I), 193-202.

Monteiro, A., \& Velho, S. (20I4). Health heat stress in the Porto Metropolitan Area - a matter of temperature or inadequate adaptation? DIE ERDE - Journal of the Geographical Society of Berlin, I45(I-2), 80-95. Retrieved from http://www.die-erde.org/index.php/die-erde/article/view/99.

Mouratidis, K. (2017). Rethinking how built environments influence subjective well-being: a new conceptual framework. Journal of Urbanism: International Research on Placemaking and Urban Sustainability, 9/ 75(April), I-I7. https://doi.org/I0.1080/I7549I75.2017.13 I0749. 
Owen, D. (2009). Green Metropolis: Why Living Smaller, Living Closer, and Driving Less Are the Keys to Sustainability (Kindle Ed). New York, USA: Penguin Publishing Group. Kindle Edition.

Speck, J. (2012). Walkable City: How Downtown Can Save America, One Step at a Time. New York, NY, USA: North Point Press. Kindle Edition.

Speck, J. (2018). Walkable City Rules: I0I Steps to Making Better Places. Washington DC, USA: Island Press.

Tavares, S. G., \& Sellars, D. (2018). Urban Liveability in Tropical Australia Through Urban Diaries and Community Engagement - UTC 3.0 International Forum Report. Cairns and Townsville, Australia. Retrieved from https://bit.ly/2CXU58P.

Tavares, S. G., \& Swaffield, S. (2017). Urban Comfort in a Future Compact City: Analysis of Open space Qualities in the Rebuilt Christchurch Central City. Landscape Review, I7(2), 5-23. https://journals.lincoln.ac.nz/index.php//r/article/view/I035.

UN-Habitat. (2016). Quito Declaration on Sustainable Cities and Human Settlements for All. Quito, Ecuador. Retrieved from http://www.eukn.eu/news/detail/agreed-final-draft-of-the-new-urbanagenda-is-now-available/.

Wolfe, C. R. (2019). Urbanism Without Effort. Washington DC, USA: Island Press.

Wolfe, C. R. (2017). Seeing the Better City. Washington DC, USA: Island Press.

\section{To cite this article:}

Tavares, S. G., Sellars, D., Mews, G., Dupré, K., Cândido, C., Towle, S. (2020). Public health and well-being in public open spaces through climate responsive urban planning and design. The Journal of Public Space, 5(2), I-6, DOI 10.3289I/jps.v5i2.I279

(c) This work is licensed under a Creative Commons Attribution - Non Commercial 4.0

International License https://creativecommons.org/licenses/by-nc/4.0/ 